\title{
Corrections: Reinstated p53 response and high anti-T-cell leukemia activity by the novel alkylating deacetylase inhibitor tinostamustine
}

\author{
S. Pützer - L. Varghese - J. von Jan - T. Braun - A. K. Giri - P. Mayer - N. Riet - S. Timonen - S. Oberbeck • \\ H. Kuusanmäki - S. Mustjoki $(1) \cdot$ M.-H. Stern $(1) \cdot$ T. Aittokallio $(1) \cdot$ S. Newrzela · A. Schrader $\cdot$ M. Herling
}

Published online: 23 October 2020

(c) The Author(s) 2020. This article is published with open access

\section{Correction to: Leukemia}

https://doi.org/10.1038/s41375-020-0772-6

This paper was published with an Open Access license which was reflected in the PDF version of the paper; however, the HTML version was originally missing this information. This has now been updated to match the PDF version.
Open Access This article is licensed under a Creative Commons Attribution 4.0 International License, which permits use, sharing, adaptation, distribution and reproduction in any medium or format, as long as you give appropriate credit to the original author(s) and the source, provide a link to the Creative Commons license, and indicate if changes were made. The images or other third party material in this article are included in the article's Creative Commons license, unless indicated otherwise in a credit line to the material. If material is not included in the article's Creative Commons license and your intended use is not permitted by statutory regulation or exceeds the permitted use, you will need to obtain permission directly from the copyright holder. To view a copy of this license, visit http://creativecommons. org/licenses/by/4.0/. 